\title{
Structural and antimicrobial properties of human pre-elafin/trappin-2 and derived peptides against Pseudomonas aeruginosa
}

\author{
Audrey Bellemare ${ }^{1}$ Nathalie Vernoux ${ }^{1,2}$, Sébastien Morin ${ }^{1,3}$, Stéphane M Gagné1, Yves Bourbonnais ${ }^{1 *}$
}

\begin{abstract}
Background: Pre-elafin/trappin-2 is a human innate defense molecule initially described as a potent inhibitor of neutrophil elastase. The full-length protein as well as the N-terminal "cementoin" and C-terminal "elafin" domains were also shown to possess broad antimicrobial activity, namely against the opportunistic pathogen $P$. aeruginosa. The mode of action of these peptides has, however, yet to be fully elucidated. Both domains of pre-elafin/trappin2 are polycationic, but only the structure of the elafin domain is currently known. The aim of the present study was to determine the secondary structures of the cementoin domain and to characterize the antibacterial properties of these peptides against $P$. aeruginosa.

Results: We show here that the cementoin domain adopts an $\alpha$-helical conformation both by circular dichroism and nuclear magnetic resonance analyses in the presence of membrane mimetics, a characteristic shared with a large number of linear polycationic antimicrobial peptides. However, pre-elafin/trappin-2 and its domains display only weak lytic properties, as assessed by scanning electron micrography, outer and inner membrane depolarization studies with P. aeruginosa and leakage of liposome-entrapped calcein. Confocal microscopy of fluorescein-labeled pre-elafin/trappin-2 suggests that this protein possesses the ability to translocate across membranes. This correlates with the finding that pre-elafin/trappin-2 and elafin bind to DNA in vitro and attenuate the expression of some $P$. aeruginosa virulence factors, namely the biofilm formation and the secretion of pyoverdine.

Conclusions: The N-terminal cementoin domain adopts $\alpha$-helical secondary structures in a membrane mimetic environment, which is common in antimicrobial peptides. However, unlike numerous linear polycationic antimicrobial peptides, membrane disruption does not appear to be the main function of either cementoin, elafin or full-length pre-elafin/trappin-2 against $P$. aeruginosa. Our results rather suggest that pre-elafin/trappin-2 and elafin, but not cementoin, possess the ability to modulate the expression of some P.aeruginosa virulence factors, possibly through acting on intracellular targets.
\end{abstract}

\section{Background}

Pseudomonas aeruginosa is a Gram-negative bacterium that rarely causes serious infections in healthy individuals. It is, however, the prevalent opportunist pathogen encountered in nosocomial infections and the major etiologic agent responsible for the morbidity, clinical deterioration and early mortality associated with patients

\footnotetext{
* Correspondence: Yves.Bourbonnais@bcm.ulaval.ca

'Département de biochimie, microbiologie et bio-informatique, Institut de biologie intégrative et des systèmes and Regroupement PROTEO, Université Laval, Québec, Qc, Canada

Full list of author information is available at the end of the article
}

suffering from cystic fibrosis (CF) [1-5]. A plethora of virulence factors expressed by $P$. aeruginosa is associated with acute and chronic infections [6]. Perhaps the most dramatic change that characterizes $P$. aeruginosa chronic infections is the transformation from a non-mucoid to a mucoid phenotype [7]. This is associated with an overproduction of alginate, which favors biofilm formation and an increased antibiotic resistance [8]. Chronic pseudomonal infections are thought to be virtually impossible to eradicate and the current strategy in the management of CF patients, which become infected in their early childhood, is to prevent or retard progression

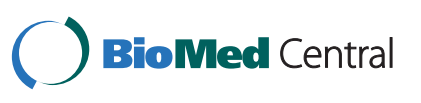

(c) 2010 Bellemare et al; licensee BioMed Central Ltd. This is an Open Access article distributed under the terms of the Creative Commons Attribution License (http://creativecommons.org/licenses/by/2.0), which permits unrestricted use, distribution, and reproduction in any medium, provided the original work is properly cited. 
to chronic infection by treating $P$. aeruginosa infections with conventional antibiotic therapy as soon as they appear $[9,10]$.

In this era of increased antibiotic resistance, the development of novel antimicrobial agents is urgently needed. In the past decade, gene-encoded short positively charged peptides, collectively known as antimicrobial peptides (AMP), have attracted much attention because of their broad antimicrobial activities and their potential use as therapeutics [11-18]. AMP are characterized by their short length (12-50 aa), polycationic (at least +2 net charge as Lys or Arg) and, usually, amphipathic characters. Among the nearly thousand identified peptides from various organisms, four classes can be distinguished based on their structures; (i) amphipathic $\alpha$-helical, (ii) $\beta$-sheet structures; (iii) extended structures, and (iv) hairpin loop stabilized by a single disulfide bridge. A common feature ascribed to AMP is their ability to interact with the negatively charged bacterial membranes and polyanionic cell surface (lipopolysaccharide (LPS) of Gram-negative and lipoteichoic acid of Gram-positive bacteria). At their lethal concentrations in vitro, they generally disrupt membrane integrity and cause bacterial lysis. Some AMP, however, do not cause membrane disruption, but act on intracellular targets such as nucleic acids [19].

We are studying the human multifunctional innate defense molecule known as pre-elafin/trappin-2. This protein is composed of two domains, an $\mathrm{N}$-terminal moiety of 38 aa known as cementoin based on its ability to be cross-linked to extracellular matrix proteins through the action of a transglutaminase and a C-terminal part of 57 aa, or elafin domain, that displays sequence similarity with whey acidic protein (WAP) [20]. This latter domain is a potent and specific inhibitor of neutrophil elastase (NE) and myeloblastin, as well as pancreatic elastase [21,22]. Its structure was determined both by X-ray crystallography in complex with pancreatic elastase and free in solution by nuclear magnetic resonance (NMR) spectroscopy [23,24]. The salient structural feature of elafin is a $\beta$-sheet stabilized by three disulfide bridges along with an inhibitory loop connected to the central $\beta$-sheet by a fourth disulfide bridge. There is no structural information regarding the cementoin domain or the full-length pre-elafin molecule.

Apart from the well-known inhibitory and anti-inflammatory properties of pre-elafin/trappin-2, previous studies also established that the full-length molecule and each of its domains possess broad antimicrobial activity, namely against the bacteria $P$. aeruginosa and $S$. aureus, and the yeast $C$. albicans [25-28]. Furthermore, adenoviral overexpression of pre-elafin/trappin-2 in a mouse model of acute P.aeruginosa infection was shown to reduce the bacterial load and to facilitate clearance of the microorganism [29]. Although it has been documented that the full-length molecule is more active than its constituent domains in vitro $[25,27,28]$, the exact mechanism of action of each of these peptides against microbial infections is largely unknown. We recently reported that the variable sensitivity of $P$. aeruginosa strains to pre-elafin/trappin-2 could be partly explained by the specific inhibition of a peptidase secreted by some, but not all, strains by the elafin domain [27]. However, both domains also display antimicrobial activity independent from the peptidase inhibitory function of elafin suggesting that the antimicrobial properties of these peptides are the sum of several unique attributes $[27,28]$.

In the present study we have determined the secondary structures of the cementoin peptide in the presence or absence of membrane mimetics. This peptide is essentially unstructured in aqueous solution but, like a large class of AMPs, adopts an $\alpha$-helical conformation in the hydrophobic membrane environment. However, when compared with magainin-2, a typical $\alpha$-helical AMP with potent lytic activity [30], the lytic properties of cementoin, elafin or pre-elafin/trappin-2 toward $P$. aeruginosa and artificial membranes are very weak. We have also tested the ability of pre-elafin/trappin-2 and its domains to interfere with the expression of known $P$. aeruginosa virulence factors and compared this activity to that of azithromycin, an antibiotic that perturbs cell to cell communication in $P$. aeruginosa and significantly retards biofilm formation [31,32]. Pre-elafin/trappin-2 and elafin, but not cementoin, were found to reduce biofilm development and the secretion of pyoverdine and this correlated with the ability of these peptides to bind DNA in vitro and to accumulate within the bacterial cytosol. Rather than causing extensive cell lysis, our data thus suggest that pre-elafin/trappin-2 and elafin attenuate the expression of some $P$. aeruginosa virulence factors, possibly through acting on an intracellular target.

\section{Results}

The cementoin domain of pre-elafin/trappin-2 adopts an $\alpha$-helical conformation in the presence of membrane mimetics

Different experiments were performed to characterize the structure of cementoin and its interaction with membranes. First, we recorded circular dichroism (CD) spectra in the presence or absence of trifluoroethanol (TFE), which mimics a membrane environment [33] (Fig. 1A). In an aqueous solution, the CD spectrum is typical of an unstructured protein with a prominent negative peak at $199 \mathrm{~nm}$. When TFE was added, the intensity of this peak decreased concomitantly with the 

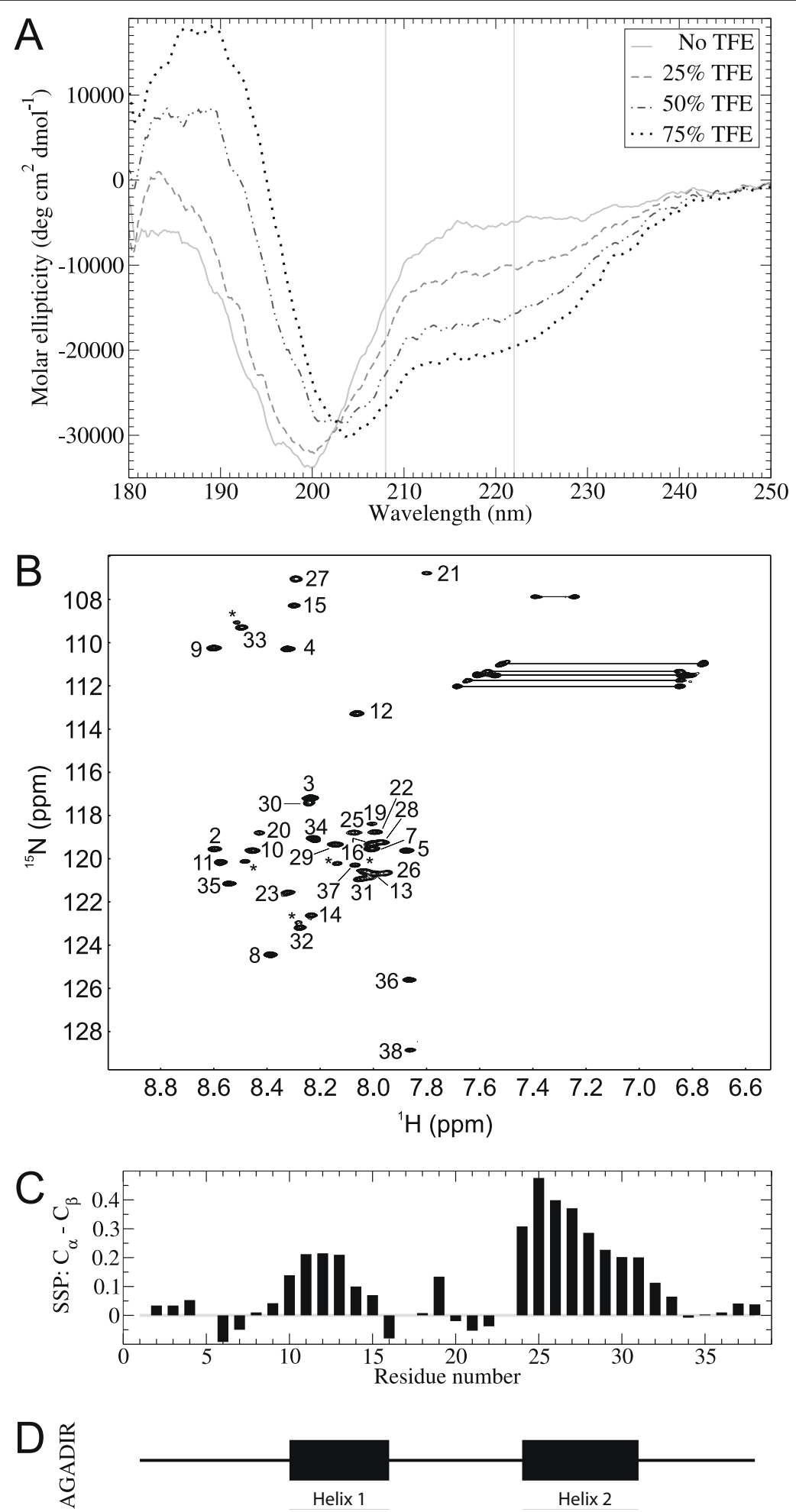

Figure 1 Biophysical characterization of cementoin. A) CD spectra of cementoin with varying concentrations of TFE (up to 75\%). The vertical lines indicate 208 and $222 \mathrm{~nm}$, i.e. characteristic wavelengths for assessing the presence of $\alpha$-helices. B) $2 \mathrm{D}^{15} \mathrm{~N}$-HSQC spectrum of cementoin in the presence of 50\% TFE. Backbone assignments are shown. Side-chain Asn, Gln and Arg doublets are depicted with a line between the two resonances while unassigned additional peaks (potentially arising from slow exchange, see text) are labeled by an asterisk (*). C) SSP analysis of backbone $C \alpha$ and $C \beta$ chemical shifts. Secondary structure predictions depend on the result where positive values infer $\alpha$-helices and negative values, $\beta$-sheets. D) Secondary structure predictions from AGADIR with $\alpha$-helices shown as black boxes. 
appearance of minima around $205 \mathrm{~nm}$ and $222 \mathrm{~nm}$ whose intensity increased with the concentration of TFE. This is characteristic of an $\alpha$-helical structure and the $\alpha$-helical content of cementoin was estimated to be $48 \%$ in $50 \%$ TFE and up to $58 \%$ in $75 \%$ TFE. The observed isodichroic point at $203 \mathrm{~nm}$ indicates that the transition between the unstructured to the $\alpha$-helical conformation is a two-state transition. Hence, a hydrophobic environment either induces or stabilizes $\alpha$ helices in cementoin. This is in agreement with the AGADIR algorithm (Fig. 1D), which predicts the formation of two $\alpha$-helices in cementoin: helix 1 with residues 10- 16 and helix 2 with residues 24-31, for a predicted total $\alpha$-helical content of $39 \%$.

Using NMR, such a formation of structure upon addition of TFE was also apparent from the more dispersed ${ }^{1} \mathrm{H}$ chemical shifts observed in the presence of $50 \%$ TFE (data not shown). These conditions were thus chosen to determine the secondary structures of cementoin. A series of triple-resonance spectra were recorded in order to assign backbone chemical shifts (Fig. 1B). From the assigned backbone chemical shifts, it was possible to predict secondary structures using the SSP approach (see Methods). This yielded two predicted helices in cementoin (Fig. 1C), similar to that predicted by AGADIR (Fig. 1D). Atomic resolution on spin relaxation data $\left(\mathrm{R}_{1}, \mathrm{R}_{2}\right.$, NOE; see additional file 1: Fig. $\left.\mathrm{S} 1 \mathrm{~A}\right)$ confirmed most of AGADIR predictions. Indeed, residues for which high flexibility is inferred (from reduced spectral density mapping of spin relaxation data, see Fig. S1 B \& C) are those located right before helix 1 as proposed by AGADIR, and directly after helix 2 . Additionally, $\mathrm{R}_{2}$ data with higher values within proposed $\alpha$ - helices, but also in the middle of the peptide would tend to indicate that this whole section of the peptide is in slow exchange. Hence, both proposed $\alpha$-helices could be nucleating points where $\alpha$ - helical structures would start appearing, enabling the transient existence of a long $\alpha$-helix spanning residues $10-31$. Of course, this structure would be transient as the NOE values are quite low $(\sim 0.5)$ for this whole stretch.

We previously showed that pre-elafin/trappin-2, elafin and particularly the cementoin domain interact strongly with negatively charged liposomes composed of phosphatidyl glycerol (PG) [27]. We used NMR with bicelles composed of a mixture of dihexanoyl phosphatidylcholine (DHPC), dimyristoyl phosphatidylcholine (DMPC) and dimyristoyl phosphatidylglycerol (DMPG) to a final ratio of $8: 3: 1$ to characterize this interaction, by measuring the translational diffusion coefficients for cementoin in the absence and presence of bicelles (Table 1 and additional file 1: Fig. S2). In the presence of bicelles, cementoin diffused with a rate much slower $\left(1.24 \times 10^{-6}\right.$ $\left.\mathrm{cm}^{2} . \mathrm{s}^{-1}\right)$ than in an aqueous environment $\left(4.28 \times 10^{-6}\right.$ $\left.\mathrm{cm}^{2} \cdot \mathrm{s}^{-1}\right)$. It is important to note here that this effect of bicelles on slowing the diffusion of cementoin is not caused by an increase in solvent viscosity, since water was found to diffuse at approximately the same rate in both conditions (Table 1). This slower rate is close to that measured for the bicelles alone $\left(0.79 \times 10^{-6} \mathrm{~cm}^{2} . \mathrm{s}^{-1}\right.$; Table 1 and Fig. S2). This finding convincingly demonstrates that an interaction exists between cementoin and bicelles. From these data, the fraction of cementoin bound to bicelles was estimated to be $87 \%$ (see Meth$o d s$ ), implying that $\sim 13 \%$ cementoin would be free in solution. These numbers could also mean that the interaction is weak and transient and that, at a given moment, $87 \%$ of cementoin are bound. The exact mechanism of interaction with membranes would depend on whether the $\alpha$-helical structures in cementoin are limited to those two $\alpha$-helices proposed by AGADIR and chemical shifts or to a longer $\alpha$-helix spanning residues 10-31 that would allow penetration of cementoin through the entire membrane width. Our diffusion data cannot discriminate between these different possibilities.

\section{Binding of pre-elafin/trappin-2 peptides to $P$. aeruginosa or artificial membranes does not cause extensive membrane disruption}

Positively charged $\alpha$-helical peptides like cementoin, are characteristic of many AMPs. These were previously shown to either disrupt membranes and cause bacterial lysis or to translocate into the bacterial cytoplasm without causing cell lysis [19]. To obtain information about the mode of action of recombinant cementoin compared

Table 1 Diffusion behavior of cementoin in $\mathrm{H}_{2} \mathrm{O}$ and bicelles.

\begin{tabular}{llcccc}
\hline Experimental condition & $\mathbf{H}_{\mathbf{2}} \mathbf{O}$ & DHPC & DMPC $^{\mathbf{1}}$ & cementoin (amide) $^{\mathbf{2}}$ & cementoin (aliphatic) $^{\mathbf{3}}$ \\
\hline cementoin & 25.22 & - & - & 4.27 & - \\
\hline DHPC: DMPC: DMPG $(8: 3: 1)$ & 21.07 & 0.68 & 0.38 & - \\
\hline DHPC: DMPC: DMPG $(8: 3: 1)+$ cementoin & 21.08 & 0.97 & 0.61 & 1.25 \\
\hline
\end{tabular}

Diffusion coefficients* are displayed for bicelles (DHPC + DMPC), $\mathrm{H}_{2} \mathrm{O}$ and cementoin in either of three experimental conditions in units of $10^{-6} \mathrm{~cm}^{2} / \mathrm{s}$.

* Calculated from $A_{G}=A_{0} \exp \left[-(\gamma \delta G)^{2}(\Delta-\delta / 3) D_{s}\right]$

${ }^{1}$ DMPG resonance was not observed and assumed to be overlapped with DMPC.

${ }^{2}$ From an isolated resonance at $7.4 \mathrm{ppm}$.

${ }^{3}$ Values are the average of three different resonances at 2.0, 2.1 and $3.0 \mathrm{ppm}$. 
with that of elafin and pre-elafin/trappin-2 on $P$. aerugi$n o s a$, we first examined the effect of these peptides on bacteria by scanning electron micrography (SEM). As shown in Fig. 2, both elafin and cementoin significantly modified the appearance of $P$. aeruginosa cell surface with clear evidence of wrinkling, blister formation and the presence of pore-like structures (white arrows in Fig. 2). At the same concentration, pre-elafin/trappin-2 appeared to affect less severely the bacterial morphology and cells harboring pore-like structures were much less abundant. The presence of pores suggests that membrane integrity is compromised by addition of these peptides. However, ghost cells were rarely observed. In sharp contrast, when $P$. aeruginosa were exposed to magainin 2, a lytic AMP, much fewer cells could be visualized by SEM and ghost cells were numerous indicating cell lysis (white arrowheads in Fig. 2).

To further document that membrane disruption may not be the primary role of cementoin, elafin and preelafin/trappin-2, the ability of these peptides to cause membrane depolarization using the fluorescent probes, $1-\mathrm{N}$-phenylnaphthylamine (NPN) and 3,3'- dipropylthiacarbocyanine $\left(\mathrm{DiSC}_{3}\right)$ was tested. NPN is a neutral hydrophobic probe that is excluded by an intact outer membrane, but is taken up into the membrane interior of an outer membrane that is disrupted by antimicrobial peptide action [34]. NPN fluoresces weakly in free solution but strongly when it crosses the outer membrane barrier into the cell. As shown in Fig. 3 (top panel), upon addition of $10 \mu \mathrm{M}$ magainin 2 a sharp increase in fluorescence was observed. The addition of $20 \mu \mathrm{M}$ pre-elafin/trappin-2 led to a much weaker fluorescence signal, and $100 \mu \mathrm{M}$ cementoin or $20 \mu \mathrm{M}$ elafin had no effects on membrane depolarization. No variation of fluorescence was seen upon addition of NPN to bacterial cells when no peptide was added. To evaluate the effects of the recombinant peptides on $P$. aeruginosa cytoplasmic membrane, the fluorescent probe $\mathrm{DiSC}_{3}$ was used. $\mathrm{DiSC}_{3}$ distributes between the cells and the medium. This cationic dye concentrates in the cytoplasmic membrane under the influence of the membrane potential resulting in a selfquenching of fluorescence. If the membrane is depolarized, the probe will be released into the medium, causing a measurable increase in fluorescence [35]. The assays were again compared with magainin 2, which can permeabilize the bacterial membranes. In contrast to a strong release of fluorescence upon addition of magainin 2, pre-elafin/trappin-2 and derived peptides weakly, if at all, induced fluorescence emission (Fig. 3; bottom panel). Our results suggest that pre-elafin/trappin- 2 and derived peptides, in contrast to magainin 2 , acted on the outer and inner membranes without causing extensive membrane depolarization.
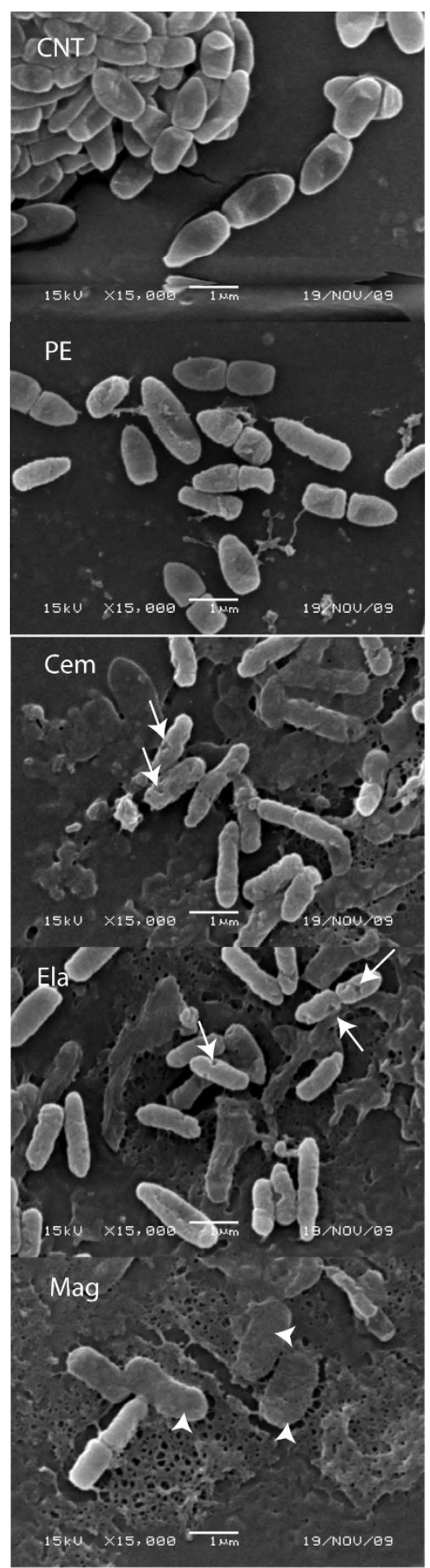

Figure 2 Scanning electron micrographs of $P$. aeruginosa incubated with cementoin, elafin, pre-elafin/trappin-2 or magainin 2. P. aeruginosa $\left(\sim 1 \times 10^{7}\right.$ in $\left.500 \mu \mathrm{L}\right)$ were incubated $2 \mathrm{~h}$ with the indicated peptides before being processed for scanning electron microscopy as described in Methods. CNT; control performed in the absence of peptides, PE; pre-elafin/trappin-2, Cem; cementoin, Ela; elafin, Mag; magainin 2. White arrows point to porelike structures and white arrowheads to ghost bacterial cells. 


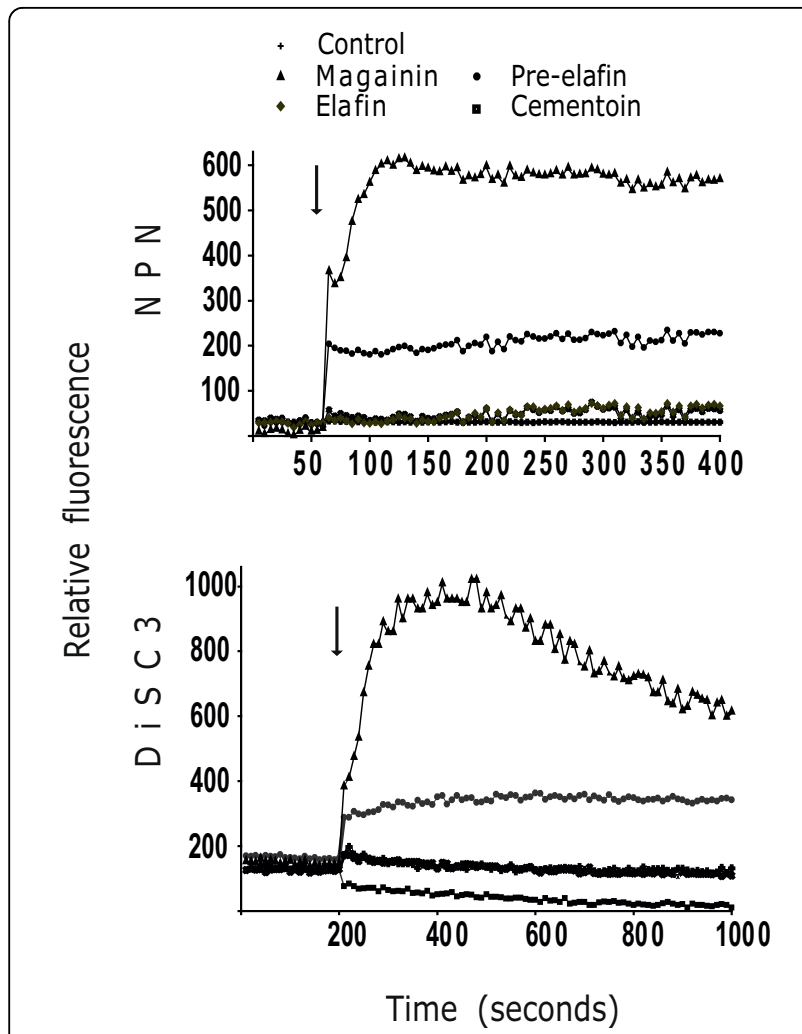

Figure 3 Depolarization of $P$. aeruginosa membranes upon incubation with magainin 2, pre-elafin/trappin-2 or derived peptides. Fluorescence emission (arbitrary units) of the probe NPN inserted into the outer membrane (top panel) or the probe $\mathrm{DiSC}_{3}$ inserted into the inner membrane (bottom panel) of $P$. aeruginosa upon addition of the indicated peptides. The controls were performed in phosphate buffer alone. Pre-elafin/trappin-2 and elafin were used at $20 \mu \mathrm{M}$, cementoin at $100 \mu \mathrm{M}$ and magainin 2 at $10 \mu \mathrm{M}$. The arrow indicates the time-point for the addition of the various peptides.
We also addressed the lytic properties of these peptides by measuring the release of calcein entrapped within PG-composed liposomes. A 15-min exposure of liposome-entrapped calcein with magainin 2 led to a $32 \%$ release of calcein relative to that measured for liposomes permeabilized with $1 \%$ Triton X-100. In contrast, no more than $5 \%$ of calcein was released by either cementoin, elafin or pre-elafin/trappin-2. We thus conclude that these peptides have very weak lytic activities. This explains our finding that no measurable MIC (minimal inhibitory concentration) could be measured even if high concentrations of peptides were tested (up to $128 \mu \mathrm{g} / \mathrm{mL}$ for pre-elafin/trappin-2 and elafin and up to $256 \mu \mathrm{g} / \mathrm{mL}$ for cementoin).

Fluorescein-labeled pre-elafin/trappin-2 incubated with $P$. aeruginosa accumulates within the cytosol and both elafin and pre-elafin/trappin-2 bind DNA in vitro

Weak membrane depolarization and leakage of liposome-entrapped calcein, while indicating little membrane disruption, does not exclude that transient pores may form upon incubation of $P$. aeruginosa with preelafin/trappin-2 and derived peptides, as suggested by SEM examination. Formation of transient pores could lead to the translocation of the peptides across membranes. We previously reported that fluorescein-labeled pre-elafin/trappin-2 heavily decorated $P$. aeruginosa cells as assessed by fluorescence microscopy [27]. Here we used confocal microscopy to examine the fate of fluorescein-labeled pre-elafin/trappin-2 upon a $1 \mathrm{~h}$ incubation with $P$. aeruginosa. As shown in Fig. 4, the whole bacterial cell was fluorescent in all consecutive $0.2 \mu \mathrm{m} \mathrm{sec}-$ tions. This is taken as evidence that pre-elafin/trappin-2
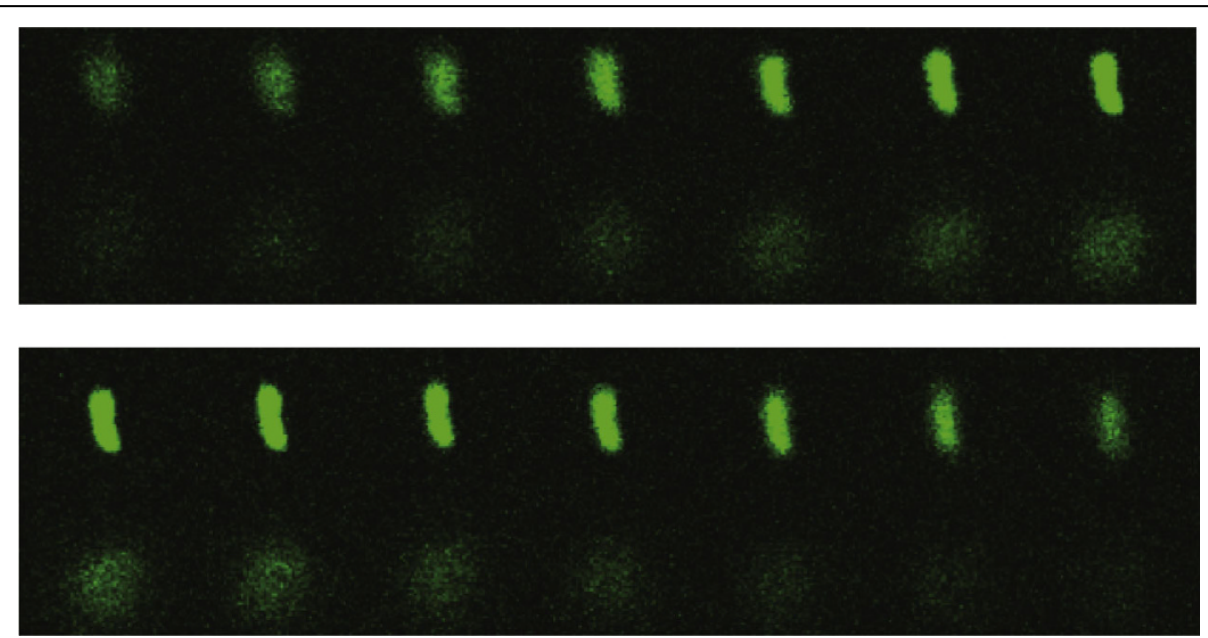

Figure 4 Confocal microscopy of $P$. aeruginosa incubated with fluorescein-labeled pre-elafin/trappin-2. Mid-logarithmic phase cultures of P. aeruginosa were incubated for $1 \mathrm{~h}$ at $37^{\circ} \mathrm{C}$ with fluorescein-labeled pre-elafin/trappin-2 and observed by confocal microscopy at $400 \times$ magnification. From left to right, consecutive $0.2 \mu \mathrm{m}$ sections of a fluorescent bacterial cell. 
not only binds the surface, but also accumulates within the bacterial cytosol.

Given the polycationic character of pre-elafin/trappin-2 and derived peptides and the apparent ability of pre-elafin/trappin-2 to traverse lipid bilayers, we considered the possibility that they could interact with nucleic acids. To test this hypothesis, we evaluated whether any of the pre-elafin/trappin-2 and derived peptides could induce an electrophoretic mobility shift (EMSA) of DNA. As shown in Fig. 5, the EMSA assay revealed that pre-elafin/trappin-2 binds to DNA in vitro at a peptide:DNA ratio of 5:1 and greater. Similar results were also obtained with the elafin domain. In contrast, no DNA shift was observed for the cementoin peptide up to a 100:1 ratio. Hence, despite the fact that the cementoin peptide has a greater positive charge $(+4)$ than elafin $(+3)$, the structure of the elafin domain appears necessary and sufficient for binding to DNA in vitro.

\section{Pre-elafin/trappin-2 and elafin attenuate the expression of known $P$. aeruginosa virulence factors}

To test whether the binding and/or translocation of the pre-elafin/trappin-2 and derived peptides could modify the behavior of $P$. aeruginosa, we assayed the expression of known virulence factors in the absence or presence of the various peptides and this was compared to that observed in the presence of azithromycin. At sublethal concentrations, azithromycin is known to interfere with the quorum sensing of $P$. aeruginosa and this was reported to reduce the expression of numerous genes encoding virulence factors as well as to retard formation of a biofilm $[31,32,36]$. We specifically assayed for the secretion of the siderophore pyoverdine, the peptidase las $\mathrm{B}$, the production of alginate and the development of a biofilm. Apart from the biofim development, which was estimated after $26 \mathrm{~h}$ of growth in the presence or absence of peptides, all assays were carried out on $24 \mathrm{~h}$ cultures of $P$. aeruginosa. As shown in Table 2, pre-elafin/trappin-2 was the most effective peptide in all assays, and at $8 \mu \mathrm{M}$ it reduced the secretion of pyoverdine and the formation of a biofilm by $\sim 40 \%$. At this concentration, it also reduced by approximately $25 \%$ the secretion of lasB and alginate although not in strictly dose-dependent manner. Interestingly, the effect of pre-elafin/trappin-2 paralleled that of azithromycin used at the same concentrations. Compared to pre-elafin/trappin-2 and azithromycin, the elafin peptide was only modestly less efficient with an observed $\sim 30 \%$ reduction on the secretion of pyoverdine and biofilm formation. The cementoin peptide alone barely $(4 \mu \mathrm{M})$ or modestly $(8 \mu \mathrm{M})$ affected the expression of these virulence factors. Hence, both pre-elafin/trappin-2 and elafin appear to attenuate the expression of some $P$. aeruginosa virulence factors and this correlates with their ability to bind DNA in vitro.

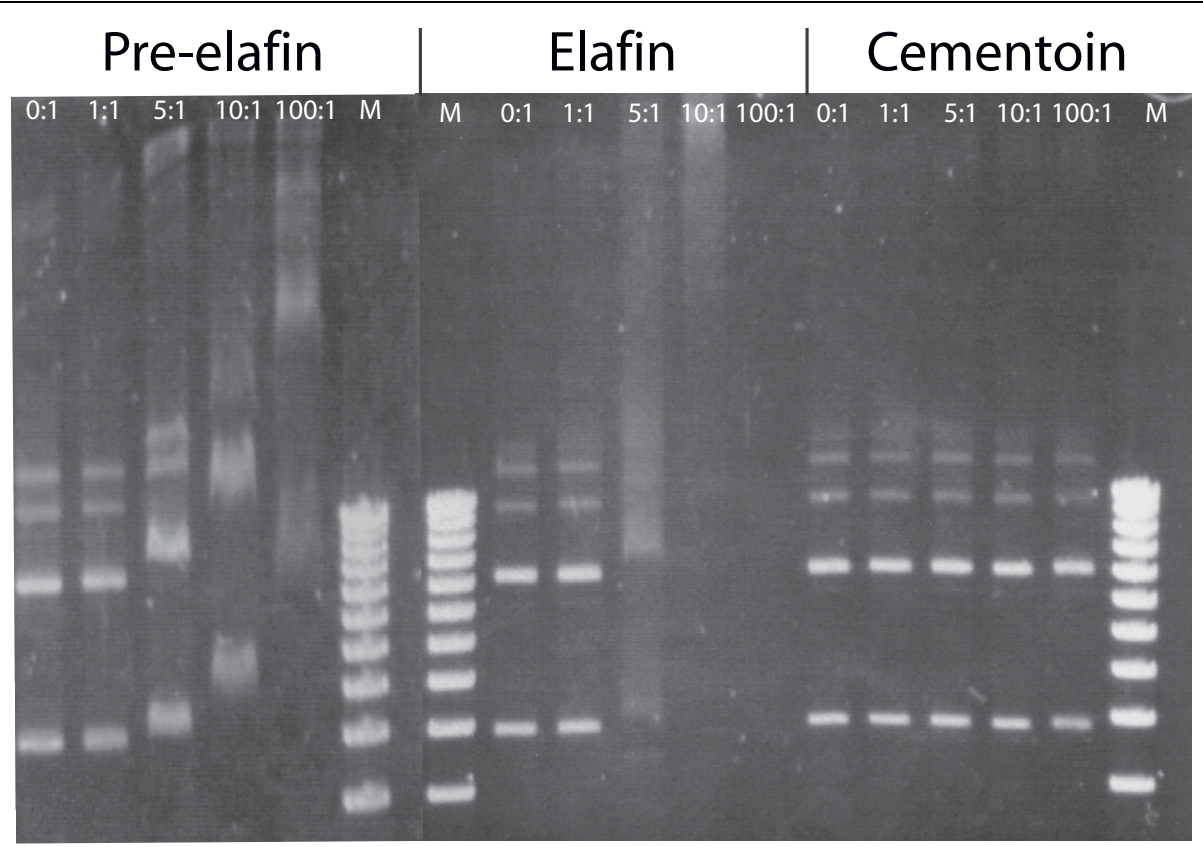

Figure 5 Electrophoretic mobility shift assay of plasmid DNA incubated in the absence or presence of pre-elafin/trappin-2, elafin and cementoin. Plasmid pRS426 (100 ng) was incubated with the indicated ratios of peptide/DNA (w/W) for $1 \mathrm{~h}$ and then analyzed by agarose gel electrophoresis followed by staining with ethidium bromide. Above are representative gels from an experiment performed in triplicata. $\mathrm{M} ; 1 \mathrm{~kb}$ DNA ladder from Invitrogen. 
Table 2 Attenuation of $P$. aeruginosa virulence factors by pre-elafin/trappin-2, elafin and cementoin

\begin{tabular}{lccccc}
\hline Peptide & {$[\boldsymbol{\mu M}]$} & $\begin{array}{c}\boldsymbol{\%}^{\mathbf{1}} \\
\text { Pyoverdine }\end{array}$ & $\begin{array}{c}\% \text { Las } \\
\boldsymbol{B}\end{array}$ & $\begin{array}{c}\% \\
\text { Alginate }\end{array}$ & $\begin{array}{c}\% \\
\text { Biofilm }\end{array}$ \\
\hline $\begin{array}{l}\text { Pre-elafin/ } \\
\text { trappin-2 }\end{array}$ & 4 & $71 \pm 2$ & $83 \pm 2$ & $76 \pm 2$ & $70 \pm 2$ \\
\hline Elafin & 8 & $59 \pm 2$ & $75 \pm 2$ & $72 \pm 2$ & $57 \pm 4$ \\
\hline Cementoin & 4 & $82 \pm 2$ & $87 \pm 4$ & $79 \pm 3$ & $86 \pm 2$ \\
& 8 & $69 \pm 1$ & $73 \pm 5$ & $77 \pm 2$ & $69 \pm 2$ \\
\hline Azithromycin & 4 & $96 \pm 2$ & $96 \pm 4$ & $95 \pm 1$ & $94 \pm 2$ \\
& 8 & $91 \pm 1$ & $88 \pm 4$ & $87 \pm 2$ & $87 \pm 2$ \\
\hline
\end{tabular}

${ }^{1}$ The results are expressed as a percentage \pm SD relative to $P$. aeruginosa cultures grown in the absence of peptides, which were set at $100 \%$. For the assays of pyoverdine and las $B$ the values represent the mean of 3 experiments performed in duplicata. For the assays of alginate and biofilm formation the values represent the mean of 3 experiments.

\section{Discussion}

The aim of the present study was to determine the secondary structures of the N-terminal moiety of pre-elafin/trappin-2 (cementoin) and to investigate the mode of action of this peptide compared to elafin and pre-elafin/ trappin-2 against $P$. aeruginosa. We have shown here by CD and NMR studies that the cementoin peptide is essentially unstructured in aqueous solution but adopts an $\alpha$-helical conformation in the presence of a membrane mimetic (TFE). This characteristic is shared with the most important class of AMP, the linear polycationic peptides [33], which include the human LL-37 peptide [37]. Whilst TFE is known to induce $\alpha$-helical structures by favoring intra hydrogen bonding, it has been demonstrated for a large number of AMP that this propensity to adopt an $\alpha$-helical conformation in TFE is also observed in the presence of artificial membranes that more closely mimic the physiological environment [33]. Hence, the secondary structures determined for cementoin in the presence of TFE are likely to be physiologically relevant. Previous studies showed that cementoin binds to the lipid core of lipopolysachharide (LPS) $[27,38]$ as well as to artificial membranes, particularly the negatively charged membranes enriched in PG [27]. We confirmed here these finding by demonstrating that the translational diffusion of cementoin in the presence of DMPG-containing bicelles is considerably slower than that of free cementoin. Furthermore, we estimated that under the conditions used (peptide:lipid millimolar ratio of $1: 200$ ), approximately $87 \%$ of the cementoin peptide was bound to bicelles.

As revealed by SEM, binding of cementoin to $P$. aeruginosa elicited obvious morphological changes such as wrinkling and blister formation on the cell surface and the presence of pore-like structures. This is reminiscent to that described earlier for the binding of pre-elafin/ trappin-2 to P. aeruginosa by Baranger et al. [28]. However, in our hands the morphological changes induced by pre-elafin/trappin-2 were not as severe as those reported earlier or to that observed in the present study with cementoin and elafin alone. The reason for this apparent discrepancy is not clear but could be due to a different peptide to bacteria ratio and/or to the actual fraction of mature elafin present in the two preparations of pre-elafin/trappin-2. It is generally assumed that the presence of pore-like structures is indicative of cell lysis. However, several lines of evidence suggest that the membrane disruption properties of cementoin, elafin and pre-elafin/trappin-2 are considerably weaker compared to that of the amphibian lytic AMP magainin 2 . First, unlike that observed with pre-elafin and derived peptides, numerous ghost cells were visualized by SEM upon incubation of $P$. aeruginosa with magainin 2 . Second, compared to this AMP, outer and inner membrane depolarization by pre-elafin/trappin-2, elafin and cementoin, as measured with the probes $\mathrm{NPN}$ and $\mathrm{DiSC}_{3}$, were significantly weaker. Third, the release of liposome-entrapped calcein by magainin 2 was six-fold greater than that measured with any of the pre-elafin/ trappin-2 derived peptides. Finally, no MIC values could be determined for cementoin, elafin or pre-elafin/trappin-2 compared to a MIC of $8 \mu \mathrm{g} / \mathrm{mL}$ for magainin 2 against $P$. aeruginosa ATCC 27853 strain [39]. We therefore tentatively conclude that membrane disruption per se may not be the main function of these peptides in vivo.

Historically, the lytic properties of a peptide were important criteria to classify it as an AMP. It is however becoming increasingly documented that several AMP possess other functions such as modulating the host response, through interacting with innate defense molecules, or modifying the microbial behavior by acting on intracellular targets $[19,40,41]$. In line with this notion, pre-elafin/trappin-2 was recently proposed to opsonize $P$. aeruginosa to facilitate its clearance by macrophage [42]. In the present work, we provided evidence that pre-elafin/trappin-2 may also traverse membranes, presumably to act on intracellular targets. A potential target could be DNA as both elafin and pre-elafin/trappin-2 were shown to bind DNA in vitro and this correlated with their ability to attenuate the expression of some $P$. aeruginosa virulence factors (see below). Buforin II is perhaps the best-documented AMP that acts on an intracellular target, the nucleic acids $[43,44]$. Investigation of the membrane translocation mechanism of buforin II led to the proposal that this peptide induces the formation of a toroidal pore similar to that described for magainin 2 [45]. However, unlike magainin 2 , the short lifetime of the pore enables translocation of the peptide without causing membrane permeabilization 
and leakage of the intracellular content. The weak membrane depolarization and calcein release observed with pre-elafin/trappin-2 and elafin suggest that these peptides might be similarly translocated across lipid bilayers without causing extensive cell lysis. However, we cannot exclude the possibility that like Gramicidin A the size of the pores, rather than their lifetime, explains the weak membrane depolarization and calcein release observed [46]. Future investigations using solid-state NMR to further characterize the interaction between pre-elafin/ trappin-2 peptides and model membranes are needed to confirm their translocation properties and the exact mechanism involved.

Azithromycin is not considered an effective antibiotic against $P$. aeruginosa due to its high MIC value ( $>64$ $\mu \mathrm{g} / \mathrm{mL} ;[31,47])$. Yet, at sublethal concentrations for $P$. aeruginosa, azithromycin was found to retard biofilm formation [32] and to reduce the production of alginate, pyocyanin and the secretion of elastase (lasB) [31,36]. We confirmed here these previous data and showed that it also reduces secretion of the siderophore pyoverdine. Both pre-elafin/trappin-2 and elafin were found to similarly affect the expression of $P$. aeruginosa virulence factors, namely the biofilm formation and the secretion of pyoverdine. Because these peptides were previously found to reduce the plating efficiency (cfu) of $P$. aeruginosa following a $3 \mathrm{~h}$ incubation with the peptides in phosphate buffer [25,27], it could be argued that the observed attenuation on the expression of virulence factors is indirect. However, we believe this is unlikely for three reasons. First, all phenotypes were tested following prolonged incubation periods (ranging from 24 to $26 \mathrm{~h}$ ) with the peptides in PSB medium. Under these conditions, the $\mathrm{A}_{595 \mathrm{~nm}}$ of the cultures at the end of the incubation were almost undistinguishable between samples incubated in the presence or absence of peptides. Second, all phenotypes were quantified taking into account the final $\mathrm{A}_{595} \mathrm{~nm}$ of the cultures. Finally, whereas the plating efficiency of $P$. aeruginosa following a $3 \mathrm{~h}$ incubation with the peptides in phosphate buffer varied considerably between different strains (i.e. ATCC 27853 vs ATCC 33348; [25,27]), this was not found to be the case for the reduced biofilm formation and secretion of pyoverdine between these two strains (data not shown). In further support to the role of pre-elafin/trappin-2 in the attenuation of $P$. aeruginosa virulence factors, it was recently reported that the A549 cell line expressing preelafin/trappin-2 reduces both the number of bacteria and the area of growing $P$. aeruginosa biofilm by approximately 50\% [48]. Although the effect of pre-elafin/trappin-2 and elafin is modest in vitro, this may contribute in vivo, along with the anti-inflammatory properties of these molecules, to prevent against $P$. aeruginosa infections.

\section{Conclusions}

We have demonstrated that the N-terminal moiety of pre-elafin/trappin-2 (cementoin) adopts an $\alpha$-helical conformation in the presence of a membrane mimetic, which is typical of a large class of AMP. Despite the morphological changes observed at the surface of $P$. aeruginosa in the presence of cementoin, elafin or pre-elafin/trappin-2, the membrane disruption properties of these peptides are weak compared to magainin 2. We provided evidence that pre-elafin/trappin-2 and elafin may act on an intracellular target, possibly DNA. Although future studies on the interaction of these peptides with artificial membranes are needed to confirm and to elucidate the mechanism of membrane translocation, both pre-elafin/trappin-2 and elafin were shown to attenuate the expression of some $P$. aeruginosa virulence factors, which may contribute to the defense against $P$. aeruginosa infection.

\section{Methods}

Bacterial, yeast strains and growth conditions

$P$. aeruginosa strain ATCC \#33348 was used in all functional assays with the pre-elafin/trappin- 2 and derived peptides. Bacteria were grown at $37^{\circ} \mathrm{C}$ with $(250 \mathrm{rpm})$ or without agitation in peptone soy broth (PSB). E. coli strain BL21(DE3) (Novagen, Mississauga, ON, Canada) was used for the recombinant production of the cementoin peptide. The $S$. cerevisiae yeast strain YGAU-Ela2

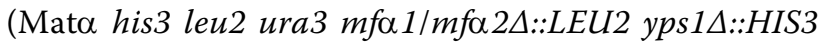
ura3::pGAU-Ela2) was used for the production of preelafin/trappin-2. This strain was constructed by integrating the plasmid pGAU-Ela2 (see below) digested by NcoI at the ura3 locus of the YBAD1 strain previously used for the production of pre-elafin/trappin-2 [49]. Yeast cells were grown at $30^{\circ} \mathrm{C}$ in yeast dextrose peptone (YPD) medium.

\section{Plasmids, oligonucleotides and DNA manipulations}

DNA manipulations, bacterial and yeast transformations were all carried out according to standard procedures [50,51]. Unless otherwise indicated, all restriction and DNA-modifying enzymes were purchased from New England Biolabs Ltd (Pickering, ON, Canada). The bacterial expression plasmid pET32-cem has been described previously for the production of the cementoin domain [27]. The yeast integration plasmid pGAU-Ela2 was constructed by first excising the $2 \mu$ origin of pVT-Ela2 through digestion with BstX1 and SmaI, fill-in with the Klenow fragment and ligation. Next, the GAL1 promoter obtained as an EcoRI-BamHI fragment from plasmid pJK6 [52] was blunt-ended with Klenow and inserted into the unique PvuII site located upstream of the preelafin fusion protein in pVT-Ela2 [49]. The resulting integration plasmid was named pGAU-Ela2. All DNA 
constructs were verified for integrity by DNA sequencing.

\section{Production and purification of recombinant pre-elafin and cementoin}

Growth conditions for the production of bacterially expressed cementoin peptide were as described previously [27]. For the production of pre-elafin/trappin-2, the yeast YGAU-Ela2 strain was first cultured 2 days at $30^{\circ} \mathrm{C}$ in $3 \mathrm{~L}$ of YPD with daily adjustments of the $\mathrm{pH}(\mathrm{pH} 6.0)$ and addition of dextrose $(1 \% \mathrm{w} / \mathrm{v})$. The culture medium was then replaced by $1 \mathrm{~L}$ of synthetic complete -uracil medium supplemented with galactose $2 \%$ and the culture was resumed for another 2 days at $30^{\circ} \mathrm{C}$ with twice daily adjustments of the $\mathrm{pH}$ and additions of yeast nitrogen base $(1 \% \mathrm{w} / \mathrm{v})$ and galactose $(1 \% \mathrm{w} / \mathrm{v})$. Uniformly ${ }^{15} \mathrm{~N}-{ }^{13} \mathrm{C}-$ labeled cementoin samples for NMR spectroscopy were prepared using ${ }^{15} \mathrm{NH}_{4} \mathrm{Cl}$ and $\left[{ }^{13} \mathrm{C}\right]$-glucose (Cambridge Isotope Laboratories, Andover, MA) as the sole nitrogen and carbon sources, as previously described [53]. Induction with $1 \mathrm{mM}$ isopropyl- $\beta$-D-thiogalactopyranoside (IPTG) was performed for $16 \mathrm{~h}$ at $37^{\circ} \mathrm{C}$.

Purification of recombinant His-tagged pre-elafin/trappin-2 from yeast culture supernatants was essentially as described $[49,54]$, except the diafiltration proceeded in two steps. The permeate from a first diafiltration performed with the cleared supernatant over a $30-\mathrm{kDa}$ cartridge was followed by concentration on a $3-\mathrm{kDa}$ cartridge. Purification of the cementoin peptide from bacterial pellets, either uniformly labeled or not, was as previously described [27]. Purified peptides were concentrated in deionized water using stirred-cells, lyophilized and stored at $-80^{\circ} \mathrm{C}$ until use. Recombinant human elafin was purchased from AnaSpec (San Jose, CA, USA).

\section{Structural analysis}

CD spectra were recorded using a JASCO J-710 instrument upgraded to J-715 by varying wavelengths between 180 and $250 \mathrm{~nm}$ with steps of $0.2 \mathrm{~nm}$. Cementoin was prepared at a concentration of $1 \mathrm{mg} / \mathrm{ml}$ in water supplemented with $0 \%$ to $75 \%$ TFE. The alpha helical content was obtained from the following formula:

$$
\mathrm{H} \alpha=100 *\left(\theta_{222 \mathrm{~nm}}-3000\right) /-39000,
$$

where $H \alpha$ is the percent $\alpha$-helix and $\theta$, the molar ellipticity per residue $\left(\mathrm{deg} \cdot \mathrm{cm}^{2} \cdot \mathrm{dmol}^{-1}\right)$, was defined as follows:

$$
\theta=\Delta \text { A.MW/C.n.l, }
$$

where MW is the peptide molecular weight (here $3948.54 \mathrm{~g} / \mathrm{mol}), \mathrm{n}$ is the number of residues in the peptide (here 38 residues), $\mathrm{C}$ is the peptide concentration (here $1 \mathrm{~g} / \mathrm{L}$ ), and 1 is the length of the optical course (here $0.01 \mathrm{~cm}$ ).

The AGADIR software http://agadir.crg.es/ developed by the Serrano's group [55-59] was used to predict the cementoin secondary structures. The parameters for ionic strength, temperature and $\mathrm{pH}$ were set to $1 \mathrm{M}$, $278^{\circ} \mathrm{K}$ and 7.0 , respectively.

NMR samples were prepared by dissolving lyophilized protein in an aqueous solution at $\mathrm{pH} 6.4$ to a final concentration of $0.5 \mathrm{mM}$ and with $60 \mu \mathrm{M}$ 2,2-dimethylsilapentane-5-sufonic acid and $10 \% \mathrm{D}_{2} \mathrm{O}$ (for chemical shift referencing and locking, respectively). The spectra were recorded at a temperature of $2^{\circ} \mathrm{C}$ (calibrated with $\mathrm{MeOH})$ on a $600 \mathrm{MHz}$ Varian INOVA spectrometer equipped with either a room temperature triple resonance probe or a $\mathrm{z}$-axis pulsed-field gradient triple resonance cold probe. Two-dimensional ${ }^{15} \mathrm{~N}$-HSQC, 3D$\mathrm{HNCO}$, 3D-HN(CO)CA, and 3D-CBCA(CO)NH spectra (Biopack, Varian Inc., Palo Alto, CA) were recorded. NMR data were processed with NMRPipe/NMRDraw [60] and analyzed with NMRView [61]. Backbone assignments proceeded within Smartnotebook v5.1.3 [62]. The chemical shift index was calculated for both $\mathrm{C}_{\alpha}$ and $\mathrm{C}_{\beta}$ for secondary structure prediction using the SSP approach [63].

Experiments for the measurement of diffusion coefficients by NMR were performed for cementoin in the absence and presence of bicelles. The procedure used was as described previously [64]. In summary, the bicelles used were a mixture of DHPC, DMPC and DMPG for a final ratio of 8:3:1 (with a (DMPC +DMPG)/DHPC ratio, i.e. long-chain to short-chain or q ratio, of 0.5). Experiments were performed with cementoin at $0.5 \mathrm{mM}$ and were recorded at $37^{\circ} \mathrm{C}$. Rates were extracted using the following equation:

$$
A_{G}=A_{0} \exp \left[-(\gamma \delta G)^{2}(\Delta-\delta / 3) D_{s}\right]
$$

Where $\gamma$ is ${ }^{1} \mathrm{H}$ gyromagnetic ratio $\left(2.6753 \times 10^{4}\right.$ rad.s $\left.{ }^{1} \cdot \mathrm{G}^{-1}\right), \delta$ is the duration of the pulse -field gradient (PFG, 0.4 s), G is the gradient strength (from 0.5 to 52 G.cm $\left.{ }^{-1}\right), \Delta$ is the time between PFG trains $(0.154 \mathrm{~s})$ and $D_{s}$ is the diffusion coefficient (in $\mathrm{cm}^{2} \cdot \mathrm{s}^{-1}$ ).

The fraction of cementoin bound to bicelles was estimated with the following equation:

$$
\mathrm{D}_{\mathrm{obs}}=\mathrm{p}_{\text {free }} \cdot \mathrm{D}_{\text {free }}+\mathrm{p}_{\text {bound }} \cdot \mathrm{D}_{\text {bound }} \text {, }
$$

where $D_{\text {obs }}, D_{\text {free }}$ and $D_{\text {bound }}$ are the diffusion coefficients for all cementoin states (observed rate: $1.24 \mathrm{~cm}^{2}$. $\left.\mathrm{s}^{-1}\right)$, for free cementoin $\left(4.28 \mathrm{~cm}^{2} . \mathrm{s}^{-1}\right)$ and for bound cementoin (by approximation, for bicelles: $0.79 \mathrm{~cm}^{2} . \mathrm{s}^{-1}$ ), respectively, and $\mathrm{p}_{\text {free }}$ and $\mathrm{p}_{\text {bound }}$ are the fractions for 
free and bound cementoin (with $\mathrm{p}_{\text {free }}+\mathrm{p}_{\mathrm{bound}}=1$ ), respectively.

Backbone chemical shifts and spin relaxation data were deposited in the BMRB under accession number 16845.

\section{Scanning electron micrography}

Scanning electron micrography (SEM) of $P$. aeruginosa $\left(\sim 1 \times 10^{7}\right.$ in $\left.500 \mu \mathrm{L}\right)$ incubated for $2 \mathrm{~h}$ in the absence or presence of the indicated peptides $(8 \mu \mathrm{M})$ was performed on a JEOL JSM-6360LV microscope essentially as described [28], except samples were placed on Alcar@ films and dehydrated by a series of incubation in alcohol (50, 70, 95 and 100\%).

\section{Outer and inner membrane depolarization of $P$. aeruginosa}

The outer membrane depolarization activity of the recombinant peptides was determined by the 1-N-phenylnaphthylamine (NPN) uptake assay of Loh et al. [34] with intact cells of $P$. aeruginosa using the Fluorescan Ascent FL microplate fluorometer. P. aeruginosa was grown with agitation to an $\mathrm{A}_{600 \mathrm{~nm}}=0.6$ and harvested by centrifugation. The cells were washed in $5 \mathrm{mM}$ HEPES, pH 7.8 and resuspended to an $\mathrm{A}_{600 \mathrm{~nm}}$ of 0.5 in the same buffer. The microtiter plate wells were supplemented with cells $(200 \mu \mathrm{L})$ and NPN dissolved in acetone was added to a final concentration of $10 \mu \mathrm{M}$. Then peptides were added to the desired concentration and the intensity of fluorescence was measured at $\lambda_{\text {ex }}=355$ $\mathrm{nm}$ and $\lambda_{\text {em }}=444 \mathrm{~nm}$.

The cytoplasmic membrane depolarization activity of the peptides was determined as previously described with the membrane potential-sensitive dye $\mathrm{DiSC}_{3}$ [35]. Briefly, $P$. aeruginosa was grown at $37^{\circ} \mathrm{C}$ with agitation to an $\mathrm{A}_{600 \mathrm{~nm}}$ of 0.6 and harvested by centrifugation. The cells were washed in $5 \mathrm{mM}$ HEPES, pH 7.8 and resuspended to an $\mathrm{A}_{600 \mathrm{~nm}}$ of 0.05 in the same buffer containing 20 $\mathrm{mM}$ glucose and $100 \mathrm{mM} \mathrm{KCl}$. The cells were first treated with 15 mM EDTA pH 8.0 to permeabilize the outer membrane and allow the dye to reach the cytoplasmic membrane. Then, a stock solution of $\mathrm{DiSC}_{3}$ was added to a final concentration of $0.4 \mu \mathrm{M}$, and quenching was allowed to occur at room temperature. The desired concentration of peptides to be tested was added. Membrane depolarization was monitored with the Fluorescan Ascent FL microplate fluorometer by observing the change in the intensity of fluorescence $\left(\lambda_{\mathrm{ex}}=646 \mathrm{~nm}, \lambda_{\mathrm{em}}=678 \mathrm{~nm}\right)$ after the addition of the peptides.

\section{Preparation of large unilamellar vesicles (liposomes) and leakage of calcein}

Large unilamellar vesicles (liposomes) containing pure phosphatidylglycerol (PG) were prepared according to the previously described procedure [27]. Liposomeentrapped calcein and removal of free calcein by Sephadex G-50 chromatography were carried out essentially as described [65].

For the calcein release assay, $10 \mu \mathrm{L}$ of liposome suspension were diluted in $10 \mathrm{mM}$ Tris- $\mathrm{HCl} \mathrm{pH} \mathrm{7.4,} 150$ $\mathrm{mM} \mathrm{NaCl}$ buffer (final vol of $100 \mu \mathrm{L}$ ) and incubated for $15 \mathrm{~min}$ at room temperature in the presence or absence (negative control) of the indicated peptides at $8 \mu \mathrm{M}$ or in the presence of $1 \%$ Triton X-100 (positive control). The change in the intensity of fluorescence $\left(\lambda_{\text {ex }}=485\right.$ $\mathrm{nm}, \lambda_{\text {em }}=527 \mathrm{~nm}$ ) was monitored with a Fluorescan Ascent FL microplate fluorometer.

\section{Confocal microscopy}

Bacteria were grown at $37^{\circ} \mathrm{C}$ with agitation in PSB medium to mid-logarithmic phase. Then, the cells were harvested by centrifugation, washed three times with 10 $\mathrm{mM}$ sodium phosphate buffer, $\mathrm{pH} 7.4$ and resuspended in the same buffer to an $A_{600}=0.1$. Bacteria were incubated with fluorescein-labeled full-length pre-elafin/trappin-2, prepared as described previously [27], for $1 \mathrm{~h}$ at $37^{\circ} \mathrm{C}$ in the dark. After incubation, cells were washed three times with phosphate buffer, and bacterial cells were mounted on a glass slide and microscopic observations $(400 \times$ magnification) of serial $0.2 \mu \mathrm{m}$ sections were done with a Zeiss LSM 310 confocal microscope. Images were taken with an Olympus DP20 camera. As a negative control, free fluorescein incubated with bacteria and washed under the same conditions gave no fluorescent signal (data not shown).

\section{DNA binding assay}

EMSA experiments were performed by mixing $100 \mathrm{ng}$ of plasmid DNA (pRS426) with increasing amounts of recombinant peptides in $20 \mu \mathrm{l}$ of binding buffer (5\% glycerol, $10 \mathrm{mM}$ Tris-HCl (pH 8.0), $1 \mathrm{mM}$ EDTA, $1 \mathrm{mM}$ DTT, $20 \mathrm{mM} \mathrm{KCl}$ and 5\% (w/v) BSA). DNA samples with or without peptides were co-incubated at room temperature for $1 \mathrm{~h}$ prior to electrophoresis on a $1.0 \%$ agarose gel.

\section{Virulence factors assays}

To assay for biofilm formation of $P$. aeruginosa an overnight culture was used to inoculate $\left(\sim 10^{6}\right.$ cells $\left./ \mathrm{ml}\right)$ peptone soy broth media in 96 wells plates (Falcon 353072) in the presence or absence of recombinant peptide. The peptides were resuspended in $10 \mathrm{mM}$ phosphate buffer ( $\mathrm{pH}$ 7.4). The plate was incubated at $30^{\circ} \mathrm{C}$ for $26 \mathrm{~h}$ without agitation. The amounts of biofilm were determined by the method described by Peeters et al. [66] using the dye crystal violet. Alginate production of $P$. aeruginosa from a $24 \mathrm{~h}$ culture was assayed according to the procedure described by Pedersen et al. [67]. The enzymatic 
assay for lasB, from the cleared supernatants of a $24 \mathrm{~h} P$. aeruginosa culture, was performed with the Congo red method as described previously [27]. The amounts of pyoverdine secreted by the bacteria were estimated by measuring the absorbance at $405 \mathrm{~nm}$ of the cleared culture supernatants from $24 \mathrm{~h}$ cultures of $P$. aeruginosa as described by Ambrosi et al. [68].

\section{Additional material}

Additional file 1: Supplementary_Figures. Fig. S1 - Spin relaxation data $\left(R_{1}, R_{2}\right.$ and $\left.N O E\right)$ and associated reduced spectral density mapping values. Fig. S2 - Diffusion behavior of cementoin, $\mathrm{H}_{2} \mathrm{O}$ and bicelles in different conditions.

\section{Acknowledgements}

We would like to thank Richard Janvier for his valuable expertise in scanning electron micrography and confocal microscopy and Steve Charette for critical reading of the manuscript. We also acknowledge the Fonds québécois de la recherche sur la nature et les technologies for a studentship to A.B., the Regroupement québécois 'PROTEO' for a fellowship to N.V. and the Fonds de la recherche en santé du Québec for a studentship to S.M. This work was supported by grants from the Natural Sciences and Engineering Research Council of Canada to S.M.G. and Y.B.

\section{Author details}

${ }^{1}$ Département de biochimie, microbiologie et bio-informatique, Institut de biologie intégrative et des systèmes and Regroupement PROTEO, Université Laval, Québec, Qc, Canada. ${ }^{2}$ INAF, Département des sciences des aliments et de nutrition Faculté des sciences de l'agriculture et de l'alimentation Université Laval. Québec, Qc, Canada. ${ }^{3}$ Division of Structural Biology, Biozentrum, University of Basel, Klingelbergstrasse 70, CH-4056 Basel, Switzerland.

\section{Authors' contributions}

$A B$ carried out the purification of peptides, prepared the samples for $C D$, NMR and SEM analyses, analyzed the spectra for backbone assignments and secondary structures, performed the experiments on the release of liposome-entrapped calcein and the expression of virulence factors and participated in drafting the manuscript. NV carried out the membrane depolarization studies, the confocal microscopy examinations with fluorescein-labeled pre-elafin/trappin-2 and drafted the manuscript. SM analyzed NMR data and drafted the manuscript. SMG designed and analyzed NMR experiments. YB conceived the study, participated in its design and wrote the manuscript. All the authors have read and approved the final manuscript. The authors declare no competing interest.

Received: 2 June 2010 Accepted: 8 October 2010 Published: 8 October 2010

\section{References}

1. Sadikot RT, Blackwell TS, Christman JW, Prince AS: Pathogen-host interactions in Pseudomonas aeruginosa pneumonia. Am J Respir Crit Care Med 2005, 171(11):1209-1223.

2. Erwin AL, VanDevanter DR: The Pseudomonas aeruginosa genome: how do we use it to develop strategies for the treatment of patients with cystic fibrosis and Pseudomonas infections? Curr Opin Pulm Med 2002, 8(6):547-551.

3. Richards MJ, Edwards JR, Culver DH, Gaynes RP: Nosocomial infections in medical intensive care units in the United States. National Nosocomial Infections Surveillance System. Crit Care Med 1999, 27(5):887-892.

4. Elkin S, Geddes D: Pseudomonal infection in cystic fibrosis: the battle continues. Expert Rev Anti Infect Ther 2003, 1(4):609-618.
5. Zhang L, Parente J, Harris SM, Woods DE, Hancock RE, Falla TJ: Antimicrobial peptide therapeutics for cystic fibrosis. Antimicrob Agents Chemother 2005, 49(7):2921-2927.

6. Kipnis E, Sawa T, Wiener-Kronish J: Targeting mechanisms of Pseudomonas aeruginosa pathogenesis. Med Mal Infect 2006, 36(2):78-91.

7. Murray TS, Egan M, Kazmierczak Bl: Pseudomonas aeruginosa chronic colonization in cystic fibrosis patients. Curr Opin Pediatr 2007, 19(1):83-88.

8. Hentzer M, Teitzel GM, Balzer GJ, Heydorn A, Molin S, Givskov M, Parsek MR: Alginate overproduction affects Pseudomonas aeruginosa biofilm structure and function. J Bacteriol 2001, 183(18):5395-5401.

9. Doring $G$, Hoiby N: Early intervention and prevention of lung disease in cystic fibrosis: a European consensus. J Cyst Fibros 2004, 3(2):67-91.

10. Hoiby N, Frederiksen B, Pressler T: Eradication of early Pseudomonas aeruginosa infection. J Cyst Fibros 2005, 4(Suppl 2):49-54.

11. Hancock RE, Lehrer R: Cationic peptides: a new source of antibiotics. Trends Biotechnol 1998, 16(2):82-88.

12. Schwab U, Gilligan P, Jaynes J, Henke D: In vitro activities of designed antimicrobial peptides against multidrug-resistant cystic fibrosis pathogens. Antimicrob Agents Chemother 1999, 43(6):1435-1440.

13. Singh PK, Tack BF, McCray PB Jr, Welsh MJ: Synergistic and additive killing by antimicrobial factors found in human airway surface liquid. Am J Physiol Lung Cell Mol Physiol 2000, 279(5):L799-805.

14. Devine DA: Antimicrobial peptides in defence of the oral and respiratory tracts. Mol Immunol 2003, 40(7):431-443.

15. Zhang L, Falla TJ: Cationic antimicrobial peptides - an update. Expert Opin Investig Drugs 2004, 13(2):97-106.

16. Toke $\mathrm{O}$ : Antimicrobial peptides: new candidates in the fight against bacterial infections. Biopolymers 2005, 80(6):717-735.

17. De Smet K, Contreras R: Human antimicrobial peptides: defensins, cathelicidins and histatins. Biotechnol Lett 2005, 27(18):1337-1347.

18. Zhang L, Falla TJ: Antimicrobial peptides: therapeutic potential. Expert Opin Pharmacother 2006, 7(6):653-663.

19. Hale JD, Hancock RE: Alternative mechanisms of action of cationic antimicrobial peptides on bacteria. Expert Rev Anti Infect Ther 2007, 5(6):951-959.

20. Schalkwijk J, Wiedow O, Hirose S: The trappin gene family: proteins defined by an $\mathrm{N}$-terminal transglutaminase substrate domain and a Cterminal four-disulphide core. Biochem J 1999, 340(Pt 3):569-577.

21. Wiedow O, Schroder JM, Gregory H, Young JA, Christophers E: Elafin: an elastase-specific inhibitor of human skin. Purification, characterization, and complete amino acid sequence. J Biol Chem 1990, 265(25):14791-14795.

22. Wiedow O, Luademann J, Utecht B: Elafin is a potent inhibitor of proteinase 3. Biochem Biophys Res Commun 1991, 174(1):6-10.

23. Tsunemi M, Matsuura $Y$, Sakakibara S, Katsube $Y$ : Crystal structure of an elastase-specific inhibitor elafin complexed with porcine pancreatic elastase determined at 1.9 A resolution. Biochemistry 1996, 35(36):11570-11576

24. Francart C, Dauchez M, Alix AJ, Lippens G: Solution structure of R-elafin, a specific inhibitor of elastase. J Mol Biol 1997, 268(3):666-677.

25. Simpson AJ, Maxwell Al, Govan JR, Haslett C, Sallenave JM: Elafin (elastasespecific inhibitor) has anti-microbial activity against gram-positive and gram-negative respiratory pathogens. FEBS Lett 1999, 452(3):309-313.

26. Meyer-Hoffert U, Wichmann N, Schwichtenberg L, White PC, Wiedow O: Supernatants of Pseudomonas aeruginosa induce the Pseudomonasspecific antibiotic elafin in human keratinocytes. Exp Dermatol 2003, 12(4):418-425.

27. Bellemare A, Vernoux N, Morisset D, Bourbonnais $Y$ : Human pre-elafin inhibits a Pseudomonas aeruginosa-secreted peptidase and prevents its proliferation in complex media. Antimicrob Agents Chemother 2008, 52(2):483-490.

28. Baranger K, Zani ML, Chandenier J, Dallet-Choisy S, Moreau T: The antibacterial and antifungal properties of trappin-2 (pre-elafin) do not depend on its protease inhibitory function. FEBS J 2008, 275(9):2008-2020.

29. Simpson AJ, Wallace WA, Marsden ME, Govan JR, Porteous DJ, Haslett C, Sallenave JM: Adenoviral augmentation of elafin protects the lung against acute injury mediated by activated neutrophils and bacterial infection. J Immunol 2001, 167(3):1778-1786.

30. Matsuzaki K: Magainins as paradigm for the mode of action of pore forming polypeptides. Biochim Biophys Acta 1998, 1376(3):391-400. 
31. Hoffmann N, Lee B, Hentzer M, Rasmussen TB, Song Z, Johansen HK, Givskov M, Hoiby N: Azithromycin blocks quorum sensing and alginate polymer formation and increases the sensitivity to serum and stationary-growth-phase killing of Pseudomonas aeruginosa and attenuates chronic $\mathrm{P}$. aeruginosa lung infection in $\mathrm{Cftr}(-/-)$ mice. Antimicrob Agents Chemother 2007, 51(10):3677-3687.

32. Favre-Bonte $\mathrm{S}$, Kohler T, Van Delden C: Biofilm formation by Pseudomonas aeruginosa: role of the C4-HSL cell-to-cell signal and inhibition by azithromycin. J Antimicrob Chemother 2003, 52(4):598-604.

33. Haney EF, Hunter HN, Matsuzaki K, Vogel HJ: Solution NMR studies of amphibian antimicrobial peptides: linking structure to function? Biochim Biophys Acta 2009, 1788(8):1639-1655.

34. Loh B, Grant C, Hancock RE: Use of the fluorescent probe 1-Nphenylnaphthylamine to study the interactions of aminoglycoside antibiotics with the outer membrane of Pseudomonas aeruginosa. Antimicrob Agents Chemother 1984, 26(4):546-551.

35. Wu M, Hancock RE: Interaction of the cyclic antimicrobial cationic peptide bactenecin with the outer and cytoplasmic membrane. J Biol Chem 1999, 274(1):29-35.

36. Nalca $Y$, Jansch $L$, Bredenbruch F, Geffers R, Buer J, Haussler S: Quorumsensing antagonistic activities of azithromycin in Pseudomonas aeruginosa PAO1: a global approach. Antimicrob Agents Chemother 2006, 50(5):1680-1688

37. Li X, Li Y, Han H, Miller DW, Wang G: Solution structures of human LL-37 fragments and NMR-based identification of a minimal membranetargeting antimicrobial and anticancer region. J Am Chem Soc 2006 128(17):5776-5785.

38. McMichael JW, Roghanian A, Jiang L, Ramage R, Sallenave JM: The antimicrobial antiproteinase elafin binds to lipopolysaccharide and modulates macrophage responses. Am J Respir Cell Mol Biol 2005, 32(5):443-452.

39. Giacometti A, Cirioni O, Barchiesi F, Fortuna M, Scalise G: In-vitro activity of cationic peptides alone and in combination with clinically used antimicrobial agents against Pseudomonas aeruginosa. J Antimicrob Chemother 1999, 44(5):641-645.

40. Brogden KA: Antimicrobial peptides: pore formers or metabolic inhibitors in bacteria? Nat Rev Microbiol 2005, 3(3):238-250.

41. Otvos $L$ Jr: Antibacterial peptides and proteins with multiple cellular targets. J Pept Sci 2005, 11(11):697-706.

42. Wilkinson TS, Dhaliwal K, Hamilton TW, Lipka AF, Farrell L, Davidson DJ, Duffin R, Morris AC, Haslett C, Govan JR, Gregory CD, Sallenave JM, Simpson AJ: Trappin-2 promotes early clearance of Pseudomonas aeruginosa through CD14-dependent macrophage activation and neutrophil recruitment. Am J Pathol 2009, 174(4):1338-1346.

43. Park CB, Kim HS, Kim SC: Mechanism of action of the antimicrobial peptide buforin II: buforin II kills microorganisms by penetrating the cell membrane and inhibiting cellular functions. Biochem Biophys Res Commun 1998, 244(1):253-257

44. Park CB, Yi KS, Matsuzaki K, Kim MS, Kim SC: Structure-activity analysis of buforin II, a histone $\mathrm{H} 2 \mathrm{~A}$-derived antimicrobial peptide: the proline hinge is responsible for the cell-penetrating ability of buforin II. Proc Natl Acad Sci USA 2000, 97(15):8245-8250.

45. Kobayashi S, Chikushi A, Tougu S, Imura Y, Nishida M, Yano Y, Matsuzaki K: Membrane translocation mechanism of the antimicrobial peptide buforin 2. Biochemistry 2004, 43(49):15610-15616.

46. Katsu T, Imamura T, Komagoe K, Masuda K, Mizushima T: Simultaneous measurements of $\mathrm{K}+$ and calcein release from liposomes and the determination of pore size formed in a membrane. Anal Sci 2007, 23(5):517-522.

47. Molinari G, Guzman CA, Pesce A, Schito GC: Inhibition of Pseudomonas aeruginosa virulence factors by subinhibitory concentrations of azithromycin and other macrolide antibiotics. J Antimicrob Chemother 1993, 31(5):681-688.

48. Li Q, Zhou X, Nie X, Yang J: The role of recombinant human elafin in the resistance of $A 549$ cells against Pseudomonas aeruginosa biofilm. Respiration 2010, 79(1):68-75.

49. Bourbonnais Y, Larouche C, Tremblay GM: Production of full-length human pre-elafin, an elastase specific inhibitor, from yeast requires the absence of a functional yapsin 1 (Yps1p) endoprotease. Protein Expr Purif 2000, 20(3):485-491.
50. Sambrook J, Fritsch EF, Maniatis T: Molecular Cloning: A Laboratory Manual, Cold Spring Harbor Laboratory. New York: Cold Spring Harbor Laboratory Press 1989.

51. Kaiser C, Michaelis S, Mitchell A: Laboratory Course Manual for Methods in Yeast Genetics, Cold Spring Harbor Laboratory. New York: Cold Spring Harbor Laboratory Press 1994.

52. Bourbonnais $Y$, Ash J, Daigle M, Thomas DY: Isolation and characterization of $S$. cerevisiae mutants defective in somatostatin expression: cloning and functional role of a yeast gene encoding an aspartyl protease in precursor processing at monobasic cleavage sites. EMBO J 1993, 12(1):285-294.

53. Doucet N, Savard PY, Pelletier JN, Gagne SM: NMR investigation of Tyr105 mutants in TEM-1 beta-lactamase: dynamics are correlated with function. J Biol Chem 2007, 282(29):21448-21459.

54. Doucet A, Bouchard D, Janelle MF, Bellemare A, Gagne S, Tremblay GM, Bourbonnais Y: Characterization of human pre-elafin mutants: full antipeptidase activity is essential to preserve lung tissue integrity in experimental emphysema. Biochem J 2007, 405(3):455-463.

55. Munoz $V$, Serrano L: Elucidating the folding problem of helical peptides using empirical parameters. Nat Struct Biol 1994, 1(6):399-409.

56. Munoz V, Serrano L: Elucidating the folding problem of helical peptides using empirical parameters. III. Temperature and $\mathrm{pH}$ dependence. J Mol Biol 1995, 245(3):297-308.

57. Munoz V, Serrano L: Elucidating the folding problem of helical peptides using empirical parameters. II. Helix macrodipole effects and rational modification of the helical content of natural peptides. J Mol Biol 1995, 245(3):275-296.

58. Munoz V, Serrano L: Development of the multiple sequence approximation within the AGADIR model of alpha-helix formation: comparison with Zimm-Bragg and Lifson-Roig formalisms. Biopolymers 1997, 41(5):495-509.

59. Lacroix E, Viguera AR, Serrano L: Elucidating the folding problem of alphahelices: local motifs, long-range electrostatics, ionic-strength dependence and prediction of NMR parameters. J Mol Biol 1998, 284(1):173-191.

60. Delaglio F, Grzesiek S, Vuister GW, Zhu G, Pfeifer J, Bax A: NMRPipe: a multidimensional spectral processing system based on UNIX pipes. $J$ Biomol NMR 1995, 6(3):277-293.

61. Johnson BA, Blevins RA: Nmr View - a Computer-Program for the Visualization and Analysis of Nmr Data. J Biomol NMR 1994, 4(5):603-614.

62. Slupsky CM, Boyko RF, Booth VK, Sykes BD: Smartnotebook: a semiautomated approach to protein sequential NMR resonance assignments. J Biomol NMR 2003, 27(4):313-321.

63. Marsh JA, Singh VK, Jia Z, Forman-Kay JD: Sensitivity of secondary structure propensities to sequence differences between alpha- and gamma-synuclein: implications for fibrillation. Protein Sci 2006, 15(12):2795-2804.

64. Marcotte I, Separovic F, Auger M, Gagne SM: A multidimensional 1 H NMR investigation of the conformation of methionine-enkephalin in fasttumbling bicelles. Biophys J 2004, 86(3):1587-1600.

65. Nan YH, Bang JK, Shin SY: Design of novel indolicidin-derived antimicrobial peptides with enhanced cell specificity and potent antiinflammatory activity. Peptides 2009, 30(5):832-838.

66. Peeters $E_{1}$ Nelis HJ, Coenye T: Comparison of multiple methods for quantification of microbial biofilms grown in microtiter plates. J Microbiol Methods 2008, 72(2):157-165.

67. Pedersen SS, Espersen F, Hoiby N, Shand GH: Purification, characterization, and immunological cross-reactivity of alginates produced by mucoid Pseudomonas aeruginosa from patients with cystic fibrosis. J Clin Microbiol 1989, 27(4):691-699.

68. Ambrosi C, Tiburzi F, Imperi F, Putignani L, Visca P: Involvement of AlgQ in transcriptional regulation of pyoverdine genes in Pseudomonas aeruginosa PAO1. J Bacteriol 2005, 187(15):5097-5107.

doi:10.1186/1471-2180-10-253

Cite this article as: Bellemare et al:: Structural and antimicrobial properties of human pre-elafin/trappin-2 and derived peptides against Pseudomonas aeruginosa. BMC Microbiology 2010 10:253. 